\title{
Difference as Punishment or Difference as Pleasure
}

\author{
From the Tower of Babel in De vulgari eloquentia \\ to the Death of Babel in Paradiso 26
}

\author{
Teodolinda Barolini
}

\begin{abstract}
Dante's linguistic treatise, De vulgari eloquentia, is not without joy in linguistic difference and invention. However, the treatise's signature view of linguistic difference is its powerfully punitive account of the Tower of Babel. Linguistic diversity, aka "confusion of tongues", is the punishment meted out to Nimrod and his followers for their presumptuous building of the Tower of Babel: thus, difference is punishment. This essay traces Dante's evolution as he moves from De vulgari eloquentia to the encounter with Nembrot (as Dante calls Nimrod) in Inferno 31 and then to Paradiso 26. The punishment of Inferno 31 is no longer differentiated language but lack of language: Dante punishes Nembrot not with linguistic diversity, but by assigning him a non-language that communicates non-sense. Adam's great discourse on linguistic creation in Paradiso 26 signals full transition: from difference as punishment to difference as pleasure.
\end{abstract}

$\mathrm{I}_{\mathrm{N}}$ IN THIS ESSAY I INTEND TO RETURN TO THE QUESTION OF DIFFERence in Dante's Commedia, as treated in The Undivine Comedy (BAROLIN I 1992), and to trace its genealogy in Dante's earlier treatise De vulgari eloquentia. Difference - linguistic, temporal, narratological, political, existential, theological — is a major theme of The Undivine Comedy, where I also outlined the origins of Dante's preoccupation with difference (aka diversity or multiplicity) in his previous works. With respect to Dante's unfinished treatise on language and vernacular eloquence, De vulgari eloquentia, I noted the hostility toward difference/diversity/multiplicity displayed by the linguistic treatise, where difference is associated with presumptuositas. ${ }^{1} \mathrm{My}$

1. See the analysis in Barolini 1992, 180-2, beginning "In some of his works, notably the De vulgari eloquentia and the Monarchia, Dante displays a hostility toward difference and multiplicity" (180). 
goal now is to elaborate my earlier thoughts regarding difference in De vulgari eloquentia and, in light of that elaboration, to reassess the relation between De vulgari eloquentia and the Commedia, particularly Paradiso 26.

Difference, in the form of linguistic diversity, functions as the divine castigation of human pride in De vulgari eloquentia. In the treatise, following Genesis 11 and Augustine's City of God 16.4, the differentiation of one original language into multiple languages is God's retaliatory scourge upon our wickedness for attempting to scale the heavens by building the Tower of Babel. The account in Genesis 11:6-7 stipulates the link between linguistic unity and transgressive human success:

et dixit: Ecce, unus est populus, et unum labium omnibus: cœperuntque hoc facere, nec desistent a cogitationibus suis, donec eas opere compleant. Venite igitur, descendamus, et confundamus ibi linguam eorum, ut non audiat unusquisque vocem proximi sui. (Genesis 11:6-7)

The LorD said, "If as one people speaking the same language they have begun to do this, then nothing they plan to do will be impossible for them. Come, let us go down and confuse their language so they will not understand each other".

In De vulgari eloquentia as well, Dante stipulates that linguistic unity creates a context in which humans work together and achieve more, stating that the builders originally spoke "one same language" and were subsequently "diversified into many languages": "qui omnes una eademque loquela deserviebant ad opus, ab opere multis diversificati loquelis desinerent et nunquam ad idem commertium convenirent" (Previously all of them had spoken one and the same language while carrying out their tasks; but now they were forced to leave off their labors, never to return to the same occupation, because they had been split up into groups speaking different languages [Dve 1.7.6]). ${ }^{2}$ Dante narrates the story of the Tower of Babel as a third prevaricatio, or transgression, followed by a third punishment: the first prevaricatio is original sin, punished by exile from Eden; the second consists of the lussuria and trucitas of the human species, punished

2. All citations from the De vulgari eloquentia are from TAVONi 2011. English translations of the work are taken from Bot Terill 1996. In both cases, passages will be cited according to the book, paragraph and line divisions (for example, Dve 1.2.2). I have also consulted Enrico Fenzi's 2012 edition. 
by the great flood; and the third is the presumptuous building of the Tower of Babel, punished by linguistic confusion.

The noun prevaricatio, "transgression", appears twice in De vulgari eloquentia: it refers to original sin on both occasions, in Dve 1.4.4 ("post prevaricationem humani generis") and 1.7.2 ("per primam prevaricationem"). ${ }^{3}$ Etymologically prevaricatio is a "going beyond", deriving from prae + varicari, a verb from which descend varcare and valicare, thus related to "varco", as in the "varco / folle d'Ulisse" of Paradiso 27.82-83. Revealing an apparent profound continuity between the earlier treatise and Paradiso, the idea of prevaricatio is reprised, as Tavoni notes in his commentary to the linguistic treatise, by Adam's "trapassar del segno" of Paradiso 26.117: "Il verbo praevaricor, intransitivo, significa 'andare oltre, fuori dal tracciato'; corrisponde dunque perfettamente alla definizione del peccato originale che darà appunto Adamo in Par. XXVI 115-17: 'Or figliuol mio, non il gustar del legno / fu per sé la cagion di tanto essilio, / ma solamente il trapassar del segno"' (TAvoni 2011, 1161 [his italics]: The intransitive verb praevaricor means to 'go beyond, outside the path; it corresponds perfectly to the definition of original sin that Adam will give in Par. 26. 115-17).

By the time we reach Paradiso 26, Dante has constructed a vast semantic and metaphoric field around the idea of trespass, featuring protagonists from classical mythology as well as biblical figures and centering on the Greek hero Ulysses. At the core of the trapassar del segno is the sin of pride, and in The Undivine Comedy's analysis of the metapoetic current of the Commedia I claim that "the terms presunzione and presumere may be said to carry a Ulyssean charge in all Dante's works . . . indeed they were invested by Dante with a special significance as early as the Convivio and the De vulgari eloquentia, before such a thematic could properly be dubbed 'Ulyssean.'"' In other words, Dante has a history of using these words in contexts that indicate his ongoing concern with the problem of intellec-

3. Botterill (1996) translates "transgression" in Dve 1.7.2, "disaster" in 1.4.4.

4. Citations from Dante's Divine Comedy are taken from the three-volume commentary by Anna Maria Chi avacci Leonardi 1991, 1994, whose text is based on Petrocchi 1966-1967. I cite passages from Dante's Commedia according to their usual divisions by canticle, canto and verses (thus, for example, Par. 26.38). Translations of the Commedia are those of Allen Mandelbaum, accessed at Digital Dante (https://digitaldante.columbia.edu/).

5. See The Undivine Comedy (BARolini 1992, 115) for my analysis of the usage of presunzione and presumere in the Commedia: the noun presunzione appears only with respect to excommunication in Purgatorio 3 and the adjective presumptuoso appears only in reference to Provenzan Salvani (1992, 114-18). 
tual arrogance, the problem to which in the Commedia he gives dramatic and metapoetic shape through the figure of Ulysses.

In De vulgari eloquentia the first and programmatic use of this key word cluster is the adjective used in 1.4.2 as a qualifier for Eve: presumptuosissima Eva. Dante is here discussing Eve's role when, by replying to the devil, she becomes, according to Scripture, the first human to engage in locutio. Dante disputes that a woman could have been the first speaker, preferring to "believe that the power of speech was given first to Adam, by Him who had just created him" (Dve 1.4.3). Putting aside Dante's interpretation of this speech act vis-à-vis the biblical antecedent, discussed by RosierCatach (2007), my interest is in the adjective presumptuosissima, the redolent superlative that marks the entrance of presumptio into the lexicon of De vulgari eloquentia. The misogyny underpinning Dante's view here is telling: Eve remains presumptuosissima, even though Dante seeks to take away her status as first speaker, the act that signaled her presumption.

The fault of the prideful presumption of the single woman of De vulgari eloquentia 1.4 .2 becomes, in its next appearance, the fault of the prideful presumption of the human race, the "culpa presumptionis humane" of 1.6.4. Following our expulsion from the garden of Eden and our near extinction in deluvial waters, in our foolish pride we presumed yet a third time, turning in De vulgari eloquentia 1.7.3 to the construction of a Tower that can reach to heaven itself: "per superbam stultitiam presumendo" (1.7.3). The participle "presumendo" at the end of 1.7 .3 is immediately echoed by the next word, the powerful verb "Presumpsit" (the subject is "uncurable man") which begins 1.7.4: "Presumpsit ergo in corde suo incurabilis homo, sub persuasione gigantis Nembroth, arte sua non solum superare naturam, sed etiam ipsum naturantem, qui Deus est" (So uncurable man, persuaded by the giant Nimrod, presumed in his heart to surpass with his art not only nature, but also nature's maker, who is God [1.7.4]). ${ }^{6}$

The extraordinary sentence that begins "Presumpsit" in De vulgari eloquentia 1.7.4 proceeds to define humankind's sin as mimetic, as representational, as always already artistic. The idea that our sin consisted in attempting to surpass with our art not only nature, but also nature's maker, anticipates the theory of mimesis (derived from Aristotle's Physics as the

6. I offer my own translation of this sentence in order to keep the Dantean word "art", as compared to Botterill's rendering "skill": "Incorrigible humanity, therefore, led astray by the giant Nimrod, presumed in its heart to outdo in skill not only nature but the source of its own nature, who is God" (Botterill 1996, ad loc.). 
maxim "ars imitatur naturam in quantum potest") that Dante outlines at the end of Inferno 11 and again in Purgatorio 10. Nembrot's attempt to surpass not only nature but also nature's maker causes him to be remembered in each cantica of the Commedia, as part of an "artistic" constellation of transgressors that merges the biblical giant with the mythological Arachne and Phaeton. The attempt to overturn the mimetic hierarchy, as described in the linguistic treatise, makes Nembrot an emblem, for Dante, of the pride inherent in human creativity, human art, human productivity, human work. Thus, Nembrot stands bewildered by the "great work" ("gran lavoro") that lies crumbled at his feet in the sculpted examples of pride in Purgatorio 12.34. This "gran lavoro" is recast by Dante's Adam as the "ovra inconsummabile" (unaccomplishable task) of Paradiso 26.125.

But difference is not only castigation in De vulgari eloquentia. God's ability to differentiate is celebrated in the treatise, as it will be (and less equivocally) in Paradiso, the cantica that devotes so much poetic energy to the fact that the One made the many. In Quaestio 47 of the Summa Theologiae, titled "De distinctione rerum in communi" (on the plurality in general of things), St. Thomas writes: "distinctio et multitudo rerum est a Deo" (the difference and multiplicity of things come from God [Gilby 1967]). In De vulgari eloquentia God's opus distinctionis is beautifully evoked in the rhetorical question in which Dante wonders whether God, who differentiated far greater things, could not have created the distinctions that cause a few words to sound: "Ipso distinguente qui maiora distinxit?" ([what surprise] if He distinguishes them who has made much greater distinctions? [Dve 1.4.6]).

Moreover, in De vulgari eloquentia Dante characterizes exile - alienation from one's homeland or patria - in a manner far different from the degredation and homelessness that characterize exile in his contemporary philosophical treatise, Convivio. Describing himself as one to whom "the whole world is a homeland, like the sea to fish" ("cui mundus est patria velut piscibus equor" [1.6.3]), Dante claims to find a patria for himself everywhere. The difference inherent in the condition of exile is thus turned into a value, and indeed Dante is open to the value of difference: to the value of swimming in a vast sea that is populated by fish of diverse stripes, by fish that are communicating, so to speak, in diverse tongues.

The treatise performs joy in human innovation and creativity, beginning with the innovation of the author himself, in the treatise's "Ulyssean" incipit: "Cum neminem ante nos de vulgaris eloquentie doctrina quicquam inveniamus tractasse" (Since I find that no one, before myself, has dealt in any way with the theory of eloquence in the vernacular [Dve 1.1.1]). When, 
in Book 2 of the linguistic treatise, Dante puts aside the fate of the human race and turns to a historiography of vernacular poetics, he is a partisan who takes overt pleasure in his supremacy. Thus the word presumere, in its six uses in the treatise, treats first the sin of the human race in Book 1 and then is used in Book 2 to regulate status among poets. In Book 2 chapter 4, Dante as author presumes ("presumpsimus") to call "poets" those who create verse in the vernacular: "quod procul dubio rationabiliter eructare presumpsimus" (this presumptuous expression is beyond question justifiable [Dve 2.4.2]). At the end of this same chapter, Dante describes inferior poets who try to go beyond their natural limits with the noun presumptuositas, used in adjectival form earlier in the treatise for Eve. Lesser poets should desist from such presumption, he writes, and if nature or laziness has made them geese, they should accept their lowly status and cease to imitate the starseeking eagle: "et a tanta presumptuositate desistant, et si anseres natura vel desidia sunt, nolint astripetam aquilam imitari" (Let them lay such presumption aside; and, if nature or their own incompetence has made them geese, let them not try to emulate the starseeking eagle [Dve 2.4.11]). The presumptuositas of the geese here stands corrected not by a castigating divinity but by Dante's very human pride in the artistry of the "starseeking eagle".

A positive view of human difference is thus not lacking in De vulgari eloquentia. Joy in human diversity is confirmed by the usage in the treatise of the verb gaudere and the noun gaudium. ${ }^{7}$ Humans are moved not by instinct but by reason, and, since reason takes diverse forms in diverse individuals - "diversificetur in singulis" — it seems almost as though each individual enjoys the privilege of being a species unto her or himself: "sua propria specie videatur gaudere" (1.3.1). ${ }^{8}$ The celebratory "diversificetur" of the phrase "diversificetur in singulis" (1.3.1) will be echoed and reversed by

7. There are two uses of the verb gaudere, in De vulgari eloquentia 1.3.1 and 2.12.3, and three uses of the noun gaudium, all in 1.4.4.

8. I diverge from Botterill's translation (1996) for this last clause. Botterill uses "almost" to qualify "everyone" ("to the point where it appears that almost everyone enjoys the existence of a unique species"), while I have instead followed the renderings of TAVONi 2011 and Fenzi 2012, for whom "almost" qualifies the idea that an individual is a species unto herself: "al punto che ciascun individuo sembra quasi far specie a sé" (TAvon i 2011, 1149); "quasi si direbbe che ognuno goda del privilegio di fare specie a sé" (Fenzi 2012, 23). Botterill captures the literal meaning of "gaudere" in "videatur gaudere", as does Fenzi, while Tavoni glosses over it. 
the punishing "diversificati" of "multis diversificati loquelis" in the Tower of Babel story (1.7.6).

Given the exalted sense of the value of being differentiated into individuals attested by "sua propria specie videatur gaudere", 9 it is interesting to note that the only other use in the treatise of the verb gaudere brings us back to the elation that accompanies poetic greatness. The verb gaudere is used to express Dante's beautiful conceit that the stanzas in a canzone "rejoice in being composed entirely of hendecasyllables": "Nam quedam stantia est que solis endecasillabis gaudet esse contexta, ut illa Guidonis de Florentia, Donna me prega, perch'io voglio dire" (For there are some stanzas that seem to rejoice in being composed entirely of hendecasyllables, as in that poem of Guido of Florence Donna me prega, perch'io voglio dire [Dve 2.12.3]).

The noun gaudium is concentrated in one chapter of the linguistic treatise, where it occurs three times in a tightly woven skein of intermixed loss and joy. Dante considers first the fall that stamps our language with woe ("heu", the wail of birth, based on the name "Eva"). He then moves backwards in time to consider the joy that must have previously marked the speech of the first man and compelled his first utterance to be the word 'God':

Nam, sicut post prevaricationem humani generis quilibet exordium sue locutionis incipit ab heu, rationabile est quod ante qui fuit inciperet a gaudio; et cum nullum gaudium sit extra Deum, sed totum in Deo, et ipse Deus totus sit gaudium, consequens est quod primus loquens primo et ante omnia dixisset "Deus". (Dve 1.4.4)

For if, since the disaster that befell the human race, the speech of every one of us has begun with 'woe!', it is reasonable that he who existed before should have begun with a cry of joy; and, since there is no joy outside God, but all [joy] is in God and since God Himself is joy itself, it follows that the first man to speak should first and before all have said 'God'.

9. Fenzi $(2012,23)$ notes the intensity of this formulation ("questa intensa frase") and glosses: "È precisamente nell'esercizio della sua natura razionale che l'uomo si rivela libero e inconfrontabile con qualsiasi altra persona, e fa specie per se stesso, proprio come avviene per gli angeli secondo Tommaso [. . . " [It is precisely in the exercise of his rational nature that each human being reveals herself to be free and unique with regard to any other person, and is a kind unto herself, just as [saint] Thomas suggests is the state of the angels]. 
In this passage, Dante constructs a before and an after: a time before the fall and a time after, "post prevaricationem humani generis" (Dve 1.4.4). In order to recover the joy of human speech, Dante turns to the before, which in the structure of his sentence he positions after. He thus ends his thought not with the fall of the human race but with the joy of the first speaker, Adam. (Dante here calls Adam "primus loquens" and discounts the idea that Eve could have been the first speaker, though he has already harshly labeled her presumptuoissima on the basis of that act.) He constructs this dialectical sentence such that the reader's final take-away is not the fall of Adam and Eve but Adam's previous joy in speech: as the "primus loquens" who "primo et ante omnia dixisset 'Deus"' (the first speaker [who] first and before all said 'God'). ${ }^{10}$

The general structural and narrative economy of De vulgari eloquentia mirrors the structure of the sentence cited above, moving from heu to guadium, from loss to joy. Book 1 moves from the self-inflicted human losses that culminate in the confusion of tongues to the idioma tripharium introduced in De vulgari eloquentia 1.8.5 and to the inventory of the languages spoken on the Italian peninsula, concluding with the characteristics of the vulgare illustre. Book 2 (and what was intended to follow Book 2, to the degree that Dante shares this information) deals with making poetry and with those who make it. In such a narrative economy the reader experiences first the fall - the somber heu or wail of human existence - and then the gaudium of creation. And we feel not only the joy of divine creation but of human creation as well: all those languages, all those poets, all those genres and meters.

Dante also takes this opportunity to tell us that the gramatica was invented precisely as a means of circumventing the debilitating effects of difference. Its inventors wanted to offset the possibility that linguistic mutability and differentiation would separate us from others. They invented gramatica lest "we should become either unable, or, at best, only partially able, to enter into contact with the deeds and authoritative writings of the ancients, or of those whose difference of location makes them different from us" (Dve 1.9.11). The gramatica thus keeps us in contact with the ancients and with those who are geographically distant from us. ${ }^{11}$ In

10. Dante's self-descriptor "neminem ante nos" aligns with Eve, who speaks "ante omnes" and now with Adam who "ante omnia dixisset 'Deus".

11. Dante here construes the cultural other precisely as he does in the Commedia, where the other is construed both temporally and geographically. Not only does Dante in the Commedia devote much attention to communication with the 
a telling phrase Dante refers to "those whose difference of location makes different from us": "illorum quos locorum diversitas facit esse diversos" (1.9.11). Language, rather than necessarily rendering us more different and separate, as per the punishment meted out for the Tower of Babel, therefore is also the means of reaching those whom diversitas facit esse diversos. From punishment and consequent loss comes a new form of unity, created by humans for human use.

Without doubt, the positive view of language as compensation for alienation or difference is already in De vulgari eloquentia. However, although we recognize the important place accorded to human invention in the linguistic treatise, we must also acknowledge the primacy of the early placement of the Tower of Babel narrative. The Babel narrative gives dramatic and performative power to the idea that loss of linguistic unity is punishment for sin. Language as we know it is the punishment visited upon our pride and the treatise's accounting for language is ineluctably bound to the logic of punishment and consequent loss.

The story of Babel is fed by primitive emotions, fostering a shame so strong that it exists even "now", Dante writes, in the present tense of the author writing the treatise. Dante takes the shame of original sin onto himself and "blushes" at the beginning of De vulgari eloquentia 1.7, where the verb "Dispudet" (it shames me) is accompanied by an authorial "heu", the sound defined in 1.4.4 as the wail that has accompanied birth ever since original sin: "Dispudet, heu, nunc humani generis ignominiam renovare! Sed quia preterire non possumus quin transeamus per illam, quanquam rubor ad ora consurgat animusque refugiat, percurremus" (Alas, how it shames me now to recall the dishonouring of the human race! But since I can make no progress without passing that way, though a blush comes to my cheek and my spirit recoils, I shall make haste to do so [Dve 1.7.1]). Dante lists our transgressions, wondering rhetorically why the punishments of banishment and extermination were not sufficient to correct us. The passage culminates with the beating that we humans deserve, authorially highlighted with an address to the reader: "Ecce, lector, quod, vel oblitus homo, vel vilipendens disciplinas priores et avertens oculos a vibicibus que

ancients, but he is also deeply concerned about the virtuous pagan whom geographical location has rendered different: the virtuous "man born on the banks of the Indus" of Paradiso 19.70-71. For this linkage, see "Inferno 4: The Cultural Other." Commento Baroliniano, Digital Dante. New York, NY: Columbia University Libraries, 2018: https:/digitaldante.columbia.edu/dante/divine-comedy/ inferno/inferno-4/ 
remanserant, tertio insurrexit ad verbera per superbam stultitiam presumendo" (And so, reader, the human race, either forgetful or disdainful of earlier punishments, and averting its eyes from the bruises that remained, came for a third time to deserve a beating, putting its trust in its own foolish pride [Dve 1.7.3]).

The Babel story enacts the law of the father and is steeped in the primal emotions of a patriarchal drama, ${ }^{12}$ as the father mercifully administers a pious beating upon his rebellious son: "O sine mensura clementia celestis imperii! Quis patrum tot sustineret insultus a filio? Sed exurgens non hostili scutica sed paterna et alias verberibus assueta, rebellantem filium pia correctione nec non memorabili castigavit" (Oh boundless mercy of the kingdom of heaven! What other father would have borne so many insults from his child? Yet, rising up not with an enemy's whip but that of a father, already accustomed to dealing out punishment, He chastised His rebellious offspring with a lesson as holy as it was memorable [Dve 1.7.5]).

All of this (frankly repellant) baggage of patriarchy and shame and pious beatings is swept away in Paradiso 26, where we meet Adam, who forcefully revises the status of Hebrew as presented in De vulgari eloquentia. Without explicitly articulating the theory that held Hebrew to be immutable (because Hebrew was created by God at the time when He created the first man), Adam nonetheless debunks it. He does so by simply and clearly stipulating the fact of Hebrew's extinction. Speaking authoritatively about the langauge that he spoke - "La lingua ch'io parlai" — Adam explains that Hebrew was subject to the same laws of time and mutability as other languages. For this reason, Hebrew was extinct before the Tower of Babel was constructed:

La lingua ch'io parlai fu tutta spenta innanzi che a l'ovra inconsummabile fosse la gente di Nembròt attenta (Par. 26.124-6)

The tongue I spoke was all extinct before the men of Nimrod set their minds upon the unaccomplishable task

Nardi writes stirringly of how Dante here sheds the "ancient prejudice" that maintained that Hebrew was a divine creation, co-created by God

12. On familial dimensions within the De vulgari eloquentia, see Cestaro 2003. 
along with Adam. Dante here, according to Nardi, reached a position that is advanced even with respect to much later thinkers like Vico. ${ }^{13}$

Dante also sheds the emotional turmoil surrounding the patriarchal drama of De vulgari eloquentia: gone are the shame-laden blushes and violent whips of the Tower of Babel story. God's pious beating of errant humanity has given way to Adam's dispassionate and philosophical presentation: a presentation that, rather than avoid Nembrot and the Tower, manages to pull the Babel story into the new narrative and to reframe it. Remarkably, for all that Adam references Nembrot and the Tower, the power of Babel is here eviscerated. Although Dante captures the haunting echo of the ancient punitive beating in the striking hapax inconsummabile, ${ }^{14}$ the very verses that cite Nembrot's "ovra inconsummabile" effectively deny the significance of that beating.

With the death of Hebrew announced by Adam comes the death of Babel. In other words, the extinction of Hebrew also extinguishes the causal logic, present in the story since the Genesis account, whereby our sinful pride was punished by linguistic "confusio": the "confusion of tongues" - diversity of language — that was meted out as punishment for our transgression..$^{15}$ The result of Paradiso 26's acceptance of the radical historicity of all human language is nothing less than the excision of the causal link that makes the myth of Babel so powerful.

Dante still held to that causal link in Inferno 31, where Virgilio addresses Nembrot as foolish and confused, "Anima sciocca" (73) and "anima con-

13. See NARdi 1949. For the "vecchio pregiudizio", see p. 244: "e in queste ricerche egli maturò il suo pensiero, finchè il vecchio pregiudizio del De vulgari eloquentia si staccò dal suo animo e cadde come una fronda inaridita"; for the later Giambattista Vico, who attempted to "salvare la verità del racconto biblico", see p. 246.

14. See Chiavacci Leonardi 1994, 730, of her commentary on the Paradiso: "Per la terza volta nel poema (cfr. Inf. XXXI 77-8; Purg. XII 34-6) ritorna il mito dell'umana superbia che così profondamente aveva colpito la mente e la fantasia di Dante. Qui il senso della storia è affidato all'aggettivo inconsummabile (che mai poteva esser consumata, cioè portata a compimento), dove è espressa l'impotenza della presunzione umana di farsi uguale a Dio".

15. Tavoni (2011, XIV) similarly notes that the differentiation of language before Babel "renders the episode irrelevant" ("il che rende l'episodio babelico irrilevante"), further commenting that Adam's claim that his language was mutable and arbitrary has the effect of "eliminating from the Babel myth its epochal value" ("Nel Paradiso Adamo dirà invece che anche la sua lingua era mutevole e arbitraria, togliendo al mito di Babele ogni valore epocale" [2011, 1076]). 
fusa" (74), reminding us of the causal link between Nembrot's tower and the confusion of tongues. Dante further presents Nembrot in two verses that highlight the causation between overweening pride and linguistic diversity: "questi è Nembrotto per lo cui mal coto / pur un linguaggio nel mondo non s'usa" (this is Nimrod, through whose wicked thought / one single language cannot serve the world [Inf. 31.77-78]). Here Dante states with utmost clarity the premise that because of Nembrot's "evil thought" ("mal coto"), one single language ("pur un linguaggio") is no longer used by humans. The causal link that is here posited between human sin and linguistic diversity indicates that the Babel myth still holds sway in Dante's mind. Although Hebrew is not explicitly mentioned in Inferno 31, the implication is, as in De vulgari eloquentia, that the one original language lost by Nembrot was Hebrew. ${ }^{16}$

There is no denying that Inferno 31 picks up from De vulgari eloquentia the castigatory concept that Nembrot's sin led to the loss of "un linguaggio" that was shared by all humans. But, at the same time, I believe that Inferno 31 demonstrates an important softening, not toward Nembrot and his sinfulness, but toward the very concept of difference, which is no longer seen as inherently sinful and hence as an appropriate punishment for transgression. In this way, I believe that we can see the position on language of Inferno 31 as a way-station toward the position on language of Paradiso 26.

In the treatise, we remember, Dante follows the biblical and Augustinian versions of the Tower of Babel story: the punishment for transgression is diversity of language. As we saw, the builders of the Tower came to the task with "one same language" and left it "diversified into many languages": "qui omnes una eademque loquela deserviebant ad opus, ab opere multis diversificati loquelis desinerent et nunquam ad idem commertium convenirent" (Previously all of them had spoken one and the same language while carrying out their tasks; but now they were forced to leave off their labours, never to return to the same occupation, because they had been split up into groups speaking different languages [1.7.6]). As each group of builders becomes a new linguistic unit, with its "one" differentiated individual language, Dante deploys the terminology that previously signified unity in such a way as to underscore the unity that is no more: "Solis etenim in uno convenientibus actu eadem loquela remansit: puta cunctis architectoribus una, cunctis saxa volventibus una, cunctis ea parantibus una; et sic de singulis operantibus accidit" (Only among those who were engaged in a particular activity did their language remain unchanged; so, for instance,

16. See Chiavacci Leonardi 1994, ad locum. 
there was one for all the architects, one for all the carriers of stones, one for all the stone-breakers, and so on for all the different operations [Dve 1.7.7]).

But in Inferno 31 Dante does not punish Nembrot by inflicting difference upon him. Dante could have found a way to indicate that Nembrot now speaks a language that is different from the language that he spoke originally, and could have indicated that Nembrot is now unintelligible to Dante and Virgilio because his language is unknown to them. Rather, the fate of Nembrot as told in Inferno 31 is discontinuous with respect to all previous versions of the Tower of Babel, including De vulgari eloquentia.

For in Inferno 31 Dante punishes Nembrot not with linguistic diversity, but by assigning him a non-language that communicates non-sense. He is explicit about this point, stating that Nembrot's language is known to no one:

Lasciànlo stare e non parliamo a vòto;

ché così è a lui ciascun linguaggio

come 'l suo ad altrui, ch'a nullo è noto.

Leave him alone-let's not waste time in talk;

for every language is to him the same

as his to others-no one knows his tongue.

Nembrot in Inferno 31 is condemned to a more extreme form of unintelligibility than the one visited upon him in De vulgari eloquentia. In previous versions of the tale, Nembrot's followers are struck with linguistic diversity, so that he as their leader loses his ability to lead: he can no longer communicate with his followers and command them. But he retains the ability to speak, and hence presumably the ability to communicate with those few followers who still speak his language. However, in Inferno 31 there is no speaker to whom Nembrot can communicate; now he is condemned to an absolute parlare a vòto, to empty speech. He is stripped of the ability to transfer cognition to language. His "evil cognition" (the "coto" of "mal coto" in verse 77 is derived from Latin cogitare) has been punished in Dante's hell by condemnation to speak a non-language that is emptied of cognition. This is truly a parlare a vòto (Inf. 31.79).

The punishment of Nembrot in Inferno 31 is more absolute than the punishment that he suffers in the biblical and Augustinian stories, where he is punished with the confusion of tongues, the differentiation of one language into many languages. But, although harsher to Nembrot, the punishment of Inferno 31 no longer classifies difference itself as a form of 
catigation. Dante has shifted away from the original versions of the story, no longer using difference itself as the punishment for the Tower of Babel. The punishment for Babel in Inferno 31 is non-language, not the creation of different languages.

Perhaps therefore we can claim that Dante has already softened his view of linguistic difference in Inferno 31. Perhaps we can posit Dante moving incrementally toward the position that he espouses in Paradiso 26, where difference is accepted, almost celebrated, as part of a necessary existential reality. The philosophical account of Paradiso 26 that takes the place of Babel removes the premise of our sinfulness and instead insists on the laws that govern all created being: the laws of time and mutability and the corruption and passing of all created things. These facts of existence may make us sad (and there may be a tinge of melancholy to Adam's speech), but they are also free of the terrible abjectness that permeates the Babel narrative.

The philosophical tone continues in the rest of Adam's speech. Following his announcement of the death of Hebrew, Adam revisits the issue of the creation of language by humans ad placitum - according to our pleasure. This issue too had been discussed in De vulgari eloquentia:

ché nullo effetto mai razionabile, per lo piacere uman che rinovella seguendo il cielo, sempre fu durabile.

Opera naturale è ch'uom favella; ma così o così, natura lascia poi fare a voi secondo che v'abbella.

For never has any thing produced by human reason been everlasting - following the heavens, men seek the new, they shift their predilections. That man should speak at all is nature's act, but how you speak - in this tongue or in that she leaves to you and to your preference.

As Dante emphasizes in the above passage, how we speak is left by nature up to us. Without any tinge of shame, Dante affirms that how we speak is dictated by what pleases us: "natura lascia / poi fare a voi secondo che v'abbella" (nature leaves to you and to your preference [Par. 26.131-2]).

In order to underscore his point that Hebrew too was manmade and subject to change, Adam then turns to the example of the name of God and 
to the changes in God's name that he has witnessed and observed. Before he (Adam) died, God had one name (I) and then subsequently He had another name $(E l)$. These changes occurred before Babel and were caused by the "uso" or habitual behavior of humans, a behavior that is habitually marked by variation and mutability, as individual humans follow their individual placitum. Our uso is a constant force for diversity and mutability, coming and going like the leaves on the bough of a tree:

Pria ch'i' scendessi a l'infernale ambascia,

I s'appellava in terra il sommo bene

onde vien la letizia che mi fascia;

e El si chiamò poi: e ciò convene,

ché l'uso d'i mortali è come fronda

in ramo, che sen va e altra vene.

(Par. 26.133-8)

Before I was sent down to Hell's torments,

on earth, the Highest Good — from which derives

the joy that now enfolds me - was called I;

and then He was called El. Such change must be:

the ways that mortals take are as the leaves

upon a branch — one comes, another goes.

We have already seen that Adam's speech on the human creation of language begins by correcting the status of Hebrew, a point to which the first man returns in the above passage with the example of the name of God. As compared to De vulgari eloquentia where Dante claims that the first word pronounced by the first speaker is "the name of God or El" (1.4.4), Dante now confirms that mutability attends even the language that names the divinity, which changed from an original I to the later El. He also corrects De vulgari eloquentia 1.9.6, whose discussion features much of the same language that we find in Adam's speech in Paradiso 26. Thus, in the below passage from De vulgari eloquentia 1.9.6, we see Latin "nullus effectus" which will become Italian "nullo effetto" (Par. 26.127), Latin "a nostro beneplacito" which will become Italian "lo piacere uman" (Par. 26.128), Latin "durabilis" which will become Italian "durabile" (Par. 26.129), and Latin "habitus" which will become Italian "l'uso d'i mortali" (Par. 26.137):

Dicimus ergo quod nullus effectus superat suam causam in quantum effectus est, quia nil potest efficere quod non est. Cum igitur omnis nostra loquela, preter illam homini primo concreatam a Deo, sit a nostro 
beneplacito reparata post confusionem illam que nil aliud fuit quam prioris oblivio, et homo sit instabilissimum atque variabilissimum animal, nec durabilis nec continua esse potest, sed sicut alia que nostra sunt, puta mores et habitus, per locorum temporumque distantias variari oportet. (Dve 1.9.6)

I say, therefore, that no effect exceeds its cause in so far as it is an effect, because nothing can bring about that which it itself is not. Since, therefore, all our language (except that created by God along with the first man) has been assembled, in haphazard fashion, in the aftermath of the great confusion that brought nothing else than oblivion to whatever language had existed before, and since human beings are highly unstable and variable animals, our language can be neither durable nor consistent with itself; but, like everything else that belongs to us (such as manners and customs), it must vary according to distances of space and time.

In De vulgari eloquentia 1.9.6 human choice in the invention of language is immediately shadowed and conditioned by the specter of the cause of that choice: our sin. Thus, "a nostro beneplacito" is followed by "reparata post confusionem", which in turn is followed by "nil aliud fuit quam prioris oblivio" (Dve 1.9.6). In other words, we humans are not afforded the opportunity to create language "a nostro beneplacito" in De vulgari eloquentia. We are only afforded the opportunity to reconstruct it, hence it is "a nostro beneplacito reparata" (Dve 1.9.6). Moreover, the reconstruction occurs in the aftermath of and as a precise function of our sin, which caused the confusion that resulted in the oblivion of the prior original language that God had made for us: the language that was co-created with Adam.

In contrast - and it is an enormous contrast, which can hardly be overstated - in Paradiso 26 our human will and pleasure and invention and creativity and art are released from the parental yoke. They are freed, and their freedom is expressed in language whose very beauty - "per lo piacere uman che rinovella" (Par. 26.128), "natura lascia / poi fare a voi secondo che v'abbella" (Par. 26.131-2 ) - surely reflects the pleasure of the poet who wrote these words. The poet chooses the verb rinovellare, enshrined at the end of Purgatorio as a signifier of positive human change, and the verb abbellare, associated with lyric love poetry, to indicate the beauty that human choice can produce. And we note "la letizia che mi fascia" of Par. 26.135, the happiness that envelopes Adam: he has refound the gaudium of De vulgari eloquentia 1.4.4. 
I will conclude with a corollary on speech and gender. In the Commedia Dante reverses the silence of the lyric lady and the errant speech of presumptuosissima Eva with that most effectively loquacious of literary ladies: the Beatrix loquax who enters the Commedia in Purgatorio 30, in the very Garden of Eden in which Eve so presumptuously spoke. Beatrix loquax then speaks for much of the rest of the poem. ${ }^{17}$ Perhaps we can align the gradual change in Dante's views of human linguistic production with a gradual change in his attitudes toward female speech. Eve's signature act of presumption is her speech, viewed as profoundly gendered speech. For, while all earth and heaven were obedient, she alone was disobedient; she, despite being female, alone, and just created ("femmina, sola, e pur testé formata") — dared to refuse all limitation, a limitation moreover expressed in profoundly gendered terms: she refused to remain under any veil — "non sofferse di star sotto alcun velo" (Purg. 29.27)..$^{18}$ Dante transitioned over time from the harsh judgment of Eve's speech in De vulgari eloquentia to the ability to imagine a female as engaged in locutio as the Beatrice of Paradiso.

The figure of presumptosissima Eva is emblematic of De vulgari eloquentia and the figure of Beatrix loquax, whose speech is not gendered (because it is multi-gendered, and multi-genred), is emblematic of the Commedia. Dante's Beatrice of the Commedia does not speak with the limitations of a woman, and her verbal authority is conferred by the author giving her access to so many genres. ${ }^{19}$ The trajectory of Dante's thought from presumptuosissima Eva to Beatrix loquax is analogous to the trajectory from difference as punishment in De vulgari eloquentia to difference as pleasure - "lo piacere uman che rinovella" (Par. 26.128) - in Paradiso 26.

We come out from under the shadow of the Tower and we are free to grow and change, rinovellando like the young plants at the end of Purgatorio: "come piante novelle / rinovellate di novella fronda" (like new plants / renewed with new leaves [Purg. 33.143-44]). Out of the shadow of the

17. I first coined the phrase "Beatrix loquax" in a footnote of The Undivine Comedy $(1992,303)$, where she came into existence precisely as a counterweight to presumptuosissima Eva.

18. See the description of Eve in Purgatorio 29.25-7: "che là dove ubidia la terra e 'l cielo, / femmina, sola e pur testé formata, / non sofferse di star sotto alcun velo" (because, where earth and heaven were obedient, / a solitary woman, just created, / found any veil at all beyond endurance).

19. For the construction of Beatrice in the Commedia, see my "Notes toward a Gendered History of Italian Literature, with a Discussion of Dante's Beatrix loquax" [BAROLINI 2006]. 
Tower, we are part of the natural order: "ché l'uso d'i mortali è come fronda / in ramo, che sen va e altra vene" (the ways that mortals take are as the leaves / upon a branch - one comes, another goes [Par. 26.137-8]). Like the fronda in ramo, we die, but we are also born: "sen va e altra vene". We die, but we also make language. We die, but we also write poems. The seeds of these views (or, better, of this attitude, because it's really a question of which side of the dialectic one privileges) are in De vulgari eloquentia. In Paradiso 26 they have reached full and magnificent flower.

Columbia University

\section{Works Cited}

Barolini, Teodolinda. 2018. Commento Baroliniano, in Digital Dante. https://digital dante.columbia.edu/dante/divine-comedy/ 10 May 2019.

2006. "Notes toward a Gendered History of Italian Literature, with a Discussion of Dante's Beatrix loquax". In Dante and the Origins of Italian Literary Culture, 360-78. New York: Fordham University Press.

- 1992. The Undivine Comedy. Princeton: Princeton University Press.

Botterill, Steven, trans. 1996. De Vulgari Eloquentia. Cambridge: Cambridge University Press.

Censtaro, Gary P. 2003. Dante and the Grammar of the Nursing Body. Notre Dame, Indiana: University of Notre Dame Press.

Chiavacci Leonardi, Anna Maria, ed. 1991, 1994. Dante Alighieri, La Divina Commedia. Inferno, Purgatorio, Paradiso. 3 vols. Milano: Mondadori.

Fenzi, Enrico, ed. and trans. 2012. De vulgari eloquentia, vol. 3 of Dante Alighieri, Le opere. Roma: Salerno.

Gilby, Thomas, ed. and trans. 1967. Thomas Aquinas, Summa Theologiae, vol. 8 (of 61 [1964-1981]). Blackfriars Edition. New York: McGraw-Hill; London: Eyre and Spottiswoode.

NARdi, Bruno. 1949. "Il linguaggio". In Dante e la cultura medievale. Bari: Laterza.

Peтrocchi, Giorgio, ed. 1966-1967. Dante Alighieri, La Commedia secondo l'antica vulgata. 4 vols. Milano: Mondadori.

Rosier-CAtach, Irène. 2007. "Il n'est pas raisonnable de croire que la très présomptueuse Ève fut le premier être parlant . . ., PoÉsie 120: 392-7

Tavoni, Mirko, ed. and trans. 2011. De vulgari eloquentia, vol. 1 of Dante Alighieri, Opere. Milano: Mondadori. 